PRÁVNE ROZPRAVY ON-SCREEN III. - Sekcia súkromného práva

online vedecká konferencia - 7. máj 2021

\title{
DÔKAZ ZÍSKANÝ NEZÁKONNÝM SPÔSOBOM V CIVILNOM KONANÍ
}

\section{THE EVIDENCE OBTAINED ILLEGALLY IN CIVIL PROCEEDINGS}

Simona Smolková1 - Jakub Dzimko ${ }^{2}$

https://doi.org/10.24040/pros.07.05.2021.ssp.209-219

\begin{abstract}
Abstrakt
Civilné súdne konanie je spojené najmä s ochranou práv a právom chránených záujmov jeho účastníkov $z$ dôvodu zabezpečenia garancie procesnej ochrany. Procesné dokazovanie, tak možno považovat’ za jeden z nosných pilierov civilného procesu. Predmetný príspevok sa venuje najmä charakteristike a analýze základných princípov v civilnom procese, ktoré bezprostredne súvisia s prípustnostou, resp. neprípustnostou dôkazu získaného nezákonným spôsobom. Príspevok sa rovnako zaoberá aj vhodnostou, či daným dôkazom možno spôsobilo zistit’ dokazovanú skutočnost'. V súvislosti s právnou úpravou prípustnosti, resp. neprípustnosti nezákonne získaného dôkazu príspevok rovnako poukazuje na úvahy de lege ferenda takto získaného dôkazu $v$ civilnom súdnom konaní.
\end{abstract}

Kl’účové slová

Civilný proces. Dokazovanie. Dôkaz. Nezákonný dôkaz.

\begin{abstract}
Civil court proceedings relate to the protection of the rights and legally protected interests of its participants to ensure the guarantee of procedural protection. Procedural evidence can thus be considered as one of the mainstays of civil proceedings. This paper deals mainly with the characteristics and analysis of the basic principles in the civil process, which are directly related to admissibility, respectively. inadmissibility of evidence obtained illegally. The article also deals with the appropriateness of whether the given evidence may have caused the proven fact to be ascertained. In connection with the legal regulation of admissibility, resp. Inadmissibility of illegally obtained evidence, the article also points to the considerations de lege ferenda of the evidence thus obtained in civil court proceedings.
\end{abstract}

\section{Keywords}

Civil proceedings. Proving. Evidence. Illegal evidence.

\footnotetext{
${ }^{1}$ Mgr. Simona Smolková - externá doktorandka, Katedra občianskeho a pracovného práva Právnickej fakulty Univerzity Mateja Bela v Banskej Bystrici, simon.smolkova@gmail.com

2 Mgr. Jakub Dzimko - interný doktorand, Katedra obchodného a finančného práva Právnickej fakulty Univerzity Mateja Bela v Banskej Bystrici, jakub.dzimko@umb.sk
} 


\section{PRÁVNE ROZPRAVY ON-SCREEN III. - Sekcia súkromného práva}

online vedecká konferencia - 7. máj 2021

\section{Úvod}

Právna úprava civilného procesu je od 1. júla 2016 obsiahnutá v troch procesných kódexoch, menovite zákon č. 160/2015 Z.z. Civilný sporový poriadok v platnom znení, zákon č. 161/2015 Z.z. Civilný mimosporový poriadok v platnom znení a zákon č. 162/2015 Z.z. Správny súdny poriadok v platnom znení. Civilné procesné právo je právne odvetvie, ktoré upravuje postup súdov, ako aj d’alších subjektov civilného konania pri zabezpečovaní práva na súdnu ochranu, a to najmä v prípade porušenia alebo ohrozenia práv a právom chránených záujmov. Civilné procesné právo, tak tvorí súhrn noriem regulujúcich samotný civilný proces.

Účelom civilného procesu je najmä objektívna ochrana práv a právom chránených záujmov jeho účastníkov konania. Za t’ažisko, resp. jeden z nosných pilierov civilného procesu môžeme považovat' procesné dokazovanie. Funkciou procesného dokazovania je najmä zistit' tie poznatky o právne relevantných skutočnostiach, ktoré sú nevyhnutné pre rozhodnutie súdu vo veci samej. Súd prostredníctvom procesného dokazovania zist'uje vhodné skutočnosti podstatné pre rozhodnutie v určitej veci, ktorá je predmetom daného konania, čím takéto skutočnosti súd získava z procesu dokazovania.

Daniela Gandžalová vymedzuje procesné dokazovanie ako „objektívnym právom upravený postup občianskoprávneho súdu, ktorého ciel’om je získanie skutkových a niekedy aj právnych poznatkov významných pre rozhodnutie vo veci samej; nakol'ko súd v civilnom procese rozhoduje autoritatívnym výrokom otázku, ktorá je predmetom daného konania, na to, aby súd mohol rozhodnút' vo veci, musí mat' dostatočné množstvo skutkových, ale aj právnych poznatkov".3

\footnotetext{
${ }^{3}$ GANDŽALOVÁ, D.: Osobitosti dokazovania v nových civilnoprávnych predpisoch so zameraním na správny súdny poriadok. In TUROŠÍK, M. - ŠEVČIKOVÁ, A.: Zborník z III. ročnika medzinárodnej vedeckej konferencie BANSKOBYSTRICKÉ ZÁMOCKÉ DNI PRÁVA na tému „Identifikácia únosnej miery autonómie právnych odvetví a súcasnej potreby ich synergie". Banská Bystrica : Belianum. Vydavatel'stvo Univerzity Mateja Bela, 2018, s. 60. [online]. Dostupné na internete: https://www.prf.umb.sk/app/cmsSiteAttachment.php?ID=4300 [cit. 2021-05-15].
} 


\section{PRÁVNE ROZPRAVY ON-SCREEN III. - Sekcia súkromného práva}

online vedecká konferencia - 7. máj 2021

\section{Inštitút dokazovania $v$ civilnom procese}

Civilný proces predstavuje legálne upravený postup súdov, na základe ktorého súdy poskytujú ochranu právam a právom chráneným záujmom tak fyzickým ako aj právnickým osobám. ${ }^{4}$

V rámci procesného dokazovania súd zist'uje a získava vhodné skutočnosti podstatné pre rozhodnutie $\mathrm{v}$ merite veci, ktorá je predmetom daného konania. Inštitút dokazovania môžeme charakterizovat' ako koherentný celok postupne vzájomne nadväzujúcich úkonov, kedy samotný proces dokazovania nepredstavuje len mechanicky zozbierané dôkazy a následne z nich mechanicky odôvodnené závery. Dokazovanie práve naopak predstavuje zložitý proces skladajúci sa z viacerých etáp, pri ktorých sa scel’ujú praktické úkony s intelektuálnou činnost'ou, zameranou najmä na navrhovanie, zaobstarávanie, vykonávanie a hodnotenie dôkazov. ${ }^{5}$

Proces dokazovania v civilnom sporovom konaní bezprostredne súvisí s koncentráciou konania, ktorá zabezpečuje, aby v konaní nenastali zbytočné priet’ahy, čím sa stranám ukladá povinnost', aby dôkazy a skutkové tvrdenia predložili včas, v dôsledku čoho súd na neskôr predložené dôkazy a tvrdenia nemusí prihliadat'. Môžeme poznamenat', že v takomto prípade sa uplatňuje rímsko-právna zásada ,, vigilatinbus iura scripta sunt “. ${ }^{6}$

Skôr ako súd pristúpi k vykonávaniu dôkazov, musí najskôr určit', čo je predmetom dokazovania. Predmet dokazovania súd determinuje na základe písomných podaní účastníkov konania, eventuálne podl'a toho, aké okolnosti súd zistí pri predbežnom prejednaní sporu $\mathrm{v}$ rámci sporových konaní alebo takisto priamo na pojednávaní. Predmet dokazovania tak v civilnom sporovom konaní predstavujú všetky dôležité skutočnosti, pre rozhodnutie vo veci, ktoré sú medzi účastníkmi sporné. Inými slovami ide o okolnosti dôležité pre konanie a ktoré majú byt' zistené, nakol'ko práve od nich priamo alebo nepriamo závisí rozhodnutie v merite veci. $^{7}$

V civilnom procese sa tak predmetom dokazovania stávajú tvrdenia o všetkých relevantných skutočnostiach, ktoré zostali pochybné, za predpokladu, že táto pochybnost'

\footnotetext{
${ }^{4}$ VLČEK, R.: Dôkazné prostriedky v občianskom súdnom konaní z právneho, sociologického a psychologického pohl'adu. Bratislava: Epos, 2006, s. 24.

${ }^{5}$ ZÁHORA, J. a kol.: Dokazovanie v trestnom konani. Praha : Leges, 2013, s. 31.

${ }^{6}$ Pozn. autorov: „Práva patria bdelým“.

7 FICOVÁ, S. a kol.: Občianske právo procesné: základné konanie. Bratislava : Univerzita Komenského v Bratislave, Právnická fakulta, Vydavatel'ské oddelenie, 2008, s. 221.
} 


\section{PRÁVNE ROZPRAVY ON-SCREEN III. - Sekcia súkromného práva}

online vedecká konferencia - 7. máj 2021

nebola odstránená zhodnými tvrdeniami účastníkov, ktoré aproboval súd tak, že si osvojil zhodné tvrdenie ako skutkové zistenia.

V súvislosti s procesom dokazovania si dovol'ujeme poukázat' na Uznesenie Ústavného súdu Slovenskej republiky, v ktorom Ústavný súd Slovenskej republiky vyslovil, že ústavnému oprávneniu domáhat' sa svojich práv na súde ,zodpovedá povinnost’ súdu nezávisle a nestranne vo veci konat' tak, aby bola právu, ktorého porušenie sa namieta, poskytnutá ochrana v medziach zákonov. Všeobecný súd však nemusí dat' odpoved' na všetky otázky nastolené účastníkom konania, ale len na tie, ktoré majú pre vec podstatný význam, prípadne dostatočne objasňujú skutkový a právny základ rozhodnutia bez toho, aby zachádzali do všetkých detailov sporu uvádzaných účastníkmi konania. Do práva na spravodlivý proces však nepatrí právo účastníka konania, aby sa všeobecný súd stotožnil s jeho právnymi názormi, navrhovaním a hodnotením dôkazov, teda za porušenie tohto základného práva nemožno považovat' neúspech

(nevyhovenie návrhu) v konaní pred všeobecným súdom (napr. I. ÚS 8/96, III. ÚS 197/02, III. ÚS 284/08). Právo na spravodlivý proces je naplnené tým, že všeobecné súdy zistia (po vykonaní dôkazov a ich vyhodnotení) skutkový stav a po použití relevantných právnych noriem vo veci rozhodnú za predpokladu, že skutkové a právne závery nie sú svojvol’né, neudržatel'né a že neboli prijaté v zrejmom omyle konajúcich súdov, ktorý by poprel zmysel a podstatu práva na spravodlivý proces “. 8

Vzhl’adom na uvedené, dokazovaním skrátene rozumieme postupov súdu za účelom zistenia skutkového stavu, ktorý je predmetom konania. Účastníci civilného sporového konania majú okrem iného, povinnost' tvrdit' a dokazovat'. Pokial' chce byt' účastník konania v spore úspešný, musí uniest' dve bremená, t.j. povinnost' predstavujúca uniest' bremeno tvrdenia a dôkazné bremeno. ${ }^{9}$

V súvislosti s povinnost'ou tvrdenia a dôkaznej povinnosti môžeme s využitím analógie poukázat' aj na Uznesenie Najvyššieho sudu Slovenskej republiky, v ktorom Najvy̌šsí súdu Slovenskej republiky vyslovil, že „,základnou normou upravujúcou bremeno tvrdenia a preukazovania je §120 ods. 1 prvá veta OSP, podl'a ktorého účastníci sú povinní označit' dôkazy na preukázanie svojich tvrdení. Toto ustanovenie ustanovuje dôkaznú povinnost' účastníkov v sporovom konaní, t. j. povinnost' označit' dôkazy na svoje tvrdenia.

\footnotetext{
${ }^{8}$ Uznesenie Ústavného súdu Slovenskej republiky zo dňa 20.01.2015, sp. zn. III. ÚS 21/2015-14.

9 ŠTEVEČEK, M. a kol.: Prednášky a texty z (nového) civilného procesu. Skriptá. Bratislava : C. H. Beck, 2017, s. 66.
} 


\section{PRÁVNE ROZPRAVY ON-SCREEN III. - Sekcia súkromného práva}

online vedecká konferencia - 7. máj 2021

Iniciatíva pri zhromažd'ovani dôkazov leži zásadne na účastníkoch konania. Účastník, ktorý neoznačil dôkazy potrebné na preukázanie svojich tvrdení, nesie nepriaznivé dôsledky v podobe takého rozhodnutia súdu, ktoré bude vychádzat' zo skutkového stavu zisteného na základe vykonaných dôkazov. Rovnaké následky postihujú aj toho účastníka, ktorý síce navrhol dôkazy o pravdivosti svojich tvrdení, no hodnotenie vykonaných dôkazov súdom vyústilo do záveru, že dokazovanie nepotvrdilo pravdivost'skutkových tvrdení účastníka “. ${ }^{10}$

V civilnom sporovom konaní tak pre dokazovanie platí zásada, že účastníci konania musia uniest' dôkazné bremeno ohl'adom svojho tvrdenia, inými slovami dôkazné bremeno je povinný uniest' ten, kto (niečo) tvrdí, kedy účastník konania resp. žalobca je okrem všeobecných náležitosti podania a označenia strán $\mathrm{v}$ žalobe povinný uviest' aj pravdivé a úplné opísanie rozhodujúcich skutočností.

\section{Základné princípy bezprostredne súvisiace s procesom dokazovania}

Za základné princípy Civilného sporového poriadku, ktoré bezprostredne súvisia s procesom dokazovania, okrem iných považujeme princíp ochrany subjektívnych práv, princíp rovnosti sporových strán, dispozičný princíp, princíp koncentrácie a arbitrárneho poriadku, princíp vol’ného hodnotenia dôkazov, princíp kontradiktórnosti a princíp legality použitel'nost' nezákonného dôkazu, pričom d'alej sa zameriame najmä na charakteristiku princípu ochrany subjektívnych práv, princípu rovnosti sporových strán, princípu vol’ného hodnotenia dôkazov a princípu legality, v ktorom je priamo vyjadrená prípustnost' resp. neprípustnost' nezákonne získaného dôkazu.

Princíp ochrany subjektívnych práv je vymedzený v článku 1 Civilného sporového poriadku, ktorý ustanovuje, že ,,spory vyplývajúce z ohrozenia alebo porušenia subjektívnych práv prejednáva a rozhoduje nezávislý a nestranný súd, ak taká právomoc nie je zákonom zverená inému orgánu. “11 V tejto súvislosti Civilný sporový poriadok zároveň odkazuje na verejné subjektívne právo na súdnu ochranu, ktoré je vymedzené v článku 46 Ústavy

\footnotetext{
10 Uznesenie Najvyššieho súdu SR zo dňa 24.02.2010, sp. zn. 4Cdo/13/2009. In KORECMAN, P. FABIANOVÁ, Z. - FRIŠTIKOVÁ, T.: Judikatúra vo veciach dokazovania v civilnom konaní. Bratislava : Wolters Kluwer, 2016, s. 48.

${ }^{11}$ Pozri čl. 1 zákona č. 160/2015 Civilný sporový poriadok v platnom znení.
} 


\section{PRÁVNE ROZPRAVY ON-SCREEN III. - Sekcia súkromného práva}

online vedecká konferencia - 7. máj 2021

Slovenskej republiky. ${ }^{12}$ Zároveň je potrebné uviest', že verejné subjektívne právo nemá nositel' vo svojej samotnej dispozícií, čo znamená, že sa ho nemožno vzdat' či previest' na iného, preto sú dohody vylučujúce súdnu ochranu absolútne neplatné.

Princíp rovnosti sporových strán je vymedzený v článku 6 Civilného sporového poriadku, kedy tento princíp zároveň patrí do ústanovnoprávného rámca civilného procesu, nakol'ko samotná Ústava Slovenskej republiky zaručuje rovnost' v prístupe orgánov v súdnej a inej právnej ochrany a tým rovnost' účastníkov pred nimi. ${ }^{13} \mathrm{~V}$ procesnoprávnej rovine princíp rovnosti sporových strán vyjadruje skutočnost', že žiadna zo sporových strán nemá voči protistrane iné ako rovnocenné postavenie. Rovnocenné postavenie účastníkov v občianskoprávnych vzt’ahoch garantuje aj ustanovenie $§ 2$ ods. 2 zákona č. 40/1964 Zb. Občiansky zákonník v znení neskorších predpisov. K uvedenému si dovol'ujeme uviest' rozhodnutie Najvyššieho súdu Slovenskej republiky, ktorý k princípu rovnosti sporových strán zaujal nasledovné stanovisko ,princíp rovnosti vychádza z čl. 47 ods. 3 Ústavy Slovenskej republiky, ktorý garantuje rovnaké postavenie účastníkov v konaní. Pod rovnakým postavením účastnikov pritom treba rozumiet' také procesné práva účastníkov, ktoré zabezpečia spravodlivý súdny proces. Pod spravodlivým súdnym procesom v ponímaní rovnakých práv treba rozumiet' povinnost' súdu zabezpečit' rovnost' zbraní, t. j. možnost' uplatnenia práv, teda rovnakú možnost’ navrhovat' dôkazy, vyjadrovat' sa $k$ vykonaným dôkazom, zúčastnit'sa na procesných úkonoch, možnost' oboznámit' sa s obsahom spisu a pod. $V$ súvislosti s námietkami dovolatel'ov dovolací súd zdôrazn̆uje, že právo navrhovat' dôkazy, resp. právo vyjadrovat’ sa $k$ vykonaným dôkazom nemožno zamieňat's rozhodovaním súdu o tom, ktoré z navrhnutých dôkazov vykoná. Súd nie je viazaný návrhmi účastníkov na vykonanie dokazovania a nie je povinný vykonat' všetky navrhnuté dôkazy “. ${ }^{14}$

Princíp vol’ného hodnotenia dôkazov je vymedzený v článku 15 Civilného sporového poriadku, pričom práve princíp vol’ného hodnotenia dôkazov výrazným spôsobom vplýva na samotné procesné dokazovanie. Stanovuje základný rámec spôsobu vykonania predložených

\footnotetext{
${ }^{12}$ Každý sa môže domáhat' zákonom ustanoveným postupom svojho práva na nezávislom a nestrannom súde a v prípadoch ustanovených zákonom na inom orgáne Slovenskej republiky. Kto tvrdí, že bol na svojich právach ukrátený rozhodnutím orgánu verejnej správy, môže sa obrátit' na súd, aby preskúmal zákonnost' takéhoto rozhodnutia, ak zákon neustanoví inak. Z právomoci súdu však nesmie byt' vylúčené preskúmanie rozhodnutí týkajúcich sa základných práv a slobôd. Každý má právo na náhradu škody spôsobenej nezákonným rozhodnutím súdu, iného štátneho orgánu či orgánu verejnej správy alebo nesprávnym úradným postupom. Podmienky a podrobnosti o súdnej a inej právnej ochrane ustanoví zákon.

${ }^{13}$ Porovnaj s čl. 46 a čl. 47 ods. 2 a 3 zákona č. 460/1992 Zb. Ústava Slovenskej republiky v platnom znení.

${ }^{14}$ Uznesenie Najvyššieho súdu Slovenskej republiky zo dňa 16.06.2009, sp. zn. 4Cdo/188/2008.
} 


\section{PRÁVNE ROZPRAVY ON-SCREEN III. - Sekcia súkromného práva}

online vedecká konferencia - 7. máj 2021

dôkazov v civilnom súdnom konaní. Podstatou a zmyslom princípu vol'ného hodnotenia dôkazov je posúdenie, akú hodnotu resp. váhu má vykonávaný dôkaz v konaní a pričom vyvodené závery sú len na úvahe súdu. ${ }^{15}$ Súd tak v zmysle materiálneho vedenia sporu hodnotí vykonané dôkazy, jednotlivé procesné úkony, ako aj tvrdenia a prednesy strán podl’a svojej vol'nej úvahy, ohraničenej jedine ústavnoprávne.

V súvislosti s uvedeným môžeme konštatovat', že je na uvážení súdu, či predmetným dôkazom tzn. jeho výpovednou hodnotou možno, dostatočne a uspokojivo preukázat' zist'ovanú skutočnost'. Je však nevyhnutné poznamenat', že vol'né hodnotenie dôkazov v žiadnom prípade neznamená hodnotenie „l'ubovol'né“. Súd preto musí v odôvodnení svojho rozhodnutia poskytnút' presvedčivé, nerozporuplné a logicky usporiadané argumenty, kedy „váhu“ jednotlivým dôkazom sudca pripisuje podl’a logického a presvedčivého použitia princípu vol'ného hodnotenia dôkazov.

Prípustnost' resp. neprípustnost' nezákonné získaného dôkazu v civilnom procese je vyjadrený v článku 16 Civilného sporového poriadku - princípe legality. Článok 16 ods. 1 Civilného sporového poriadku stanovuje princíp legality „, Súd postupuje a rozhoduje v súlade s platnými a účinnými právnymi predpismi pri zohl'adnení ich vzájomného vztahu a v súlade so základnými princípmi tohto zákona. "16

Článok 16 ods. 2 Civilného sporového poriadku so znením ,S Súd pri prejednávaní a rozhodovani veci nezohl'adňuje skutočnosti a dôkazy, ktoré boli ziskané v rozpore so zákonom, ibaže vykonanie dôkazu získaného v rozpore so zákonom je odôvodnené uplatnením čl. 3 ods. 1. " predstavuje výnimku z princípu legality pri vykonávaní a hodnotení dôkazov. ${ }^{17}$

\section{Prípustnost'/neprípustnost' dôkazu získaného nezákonným spôsobom}

Civilné sporové konanie sa v zásade spravuje (okrem iných) princípom legality, ktorý sa premieta do celého súdneho procesu, nevynímajúc proces dokazovania. Princíp legality však neplatí absolútne a procesná právna úprava pripúšt'a výnimku z tohto pravidla, a to najmä vtedy ak je vykonanie nezákonného dôkazu možné odôvodnit’ podl’a článku 3 ods. 1

\footnotetext{
${ }^{15}$ Porovnaj s čl. 15 ods. 1 zákona č. 160/2015 Z. z. Civilný sporový poriadok v platnom znení.

${ }^{16}$ Pozri čl. 16 ods. 1 zákona č. 160/2015 Civilný sporový poriadok v platnom znení.

${ }^{17}$ Pozri čl. 16 ods. 2 zákona č. 160/2015 Civilný sporový poriadok v platnom znení.
} 


\section{PRÁVNE ROZPRAVY ON-SCREEN III. - Sekcia súkromného práva}

online vedecká konferencia - 7. máj 2021

Civilného sporového poriadku. ${ }^{18}$ Ide najmä o situáciu, kedy je možné vykonanie dôkazu získaného contra legem odôvodnit’ v zmysle ústavnokonformného výkladu. ${ }^{19}$

Faktory, ktoré budú podmieňovat' uvažovanie súdu pri posudzovaní prípustnosti resp. neprípustnosti nezákonne získaného dôkazu, súd uskutočňuje prostredníctvom testu proporcionality. Test proporcionality (pozostáva z trojkrokového posúdenia a to vhodnosti, potrebnosti a primeranosti porušenia práva druhej strany) je postup súdu, pri ktorom súd hodnotí to, ktoré právo garantované Ústavou Slovenskej republiky v danom prípade zaváži viac a má väčšiu dôležitost'. ${ }^{20}$

Použitel'nost' testu proporcionality pri posudzovaní nezákonne získaného dôkazu, je obmedzená stavom dôkaznej núdze, to znamená že $\mathrm{v}$ prípade existencie iných dôkazov v zásade vykonanie nezákonného dôkazu nie je potrebné. Použitím testu proporcionality, vzájomne kolidujúcich ústavných práv, súd môže vykonat' dôkaz získaný v rozpore so zákonom. S poukazom na uvedené, súd tak môže vykonat' resp. pripustit' dôkaz získaný $\mathrm{v}$ rozpore so zákonom, pokial' je právo proti strany v konkrétnom prípade ústavnokonformne posúdené ako silnejšie právo než porušené právo toho, na koho úkor sa právo vykonáva. ${ }^{21}$

Pred novou právnou úpravou, ktorá je účinná od 01. júla 2016 a ktorá nahradila viac ako pät' dekád platný a účinný Občiansky súdny poriadok, neboli jednoznačné a ustálené doktrinálne a ani judikované názory procesnej prípustností resp. neprípustností nezákonne získaného dôkazu. V prvopočiatkoch bol postoj judikatúry k testu proporcionality odmietavý resp. sa ním vôbec nezaoberala a vychádzala z toho, že nezákonný dôkaz možno použit' len v prípade udelenia súhlasu druhého účastníka (typickým príkladom je zaznamenávanie osobné alebo telefonického rozhovoru viacerých osôb). V predmetnom prípade bola

\footnotetext{
${ }^{18}$ Každé ustanovenie tohto zákona je potrebné vykladat’ v súlade s Ústavou Slovenskej republiky, verejným poriadkom, princípmi, na ktorých spočíva tento zákon, s medzinárodnoprávnymi záväzkami Slovenskej republiky, ktoré majú prednost' pred zákonom, judikatúrou Európskeho súdu pre l'udské práva a Súdneho dvora Európskej únie, a to s trvalým zretel’om na hodnoty, ktoré sú nimi chránené.

${ }^{19}$ Ustanovenie čl. 16 ods. 2 Civilného sporového poriadku je teda potrebné vykladat' a aplikovat' v spojení s ustanovením čl. 3 ods. 1 Civilného sporového poriadku, ktoré ustanovuje, že každé ustanovenie CSP je potrebné vykladat' ústavnokonformne a eurokonformne, rešpektujúc judikatúru ESLPP a Súdneho dvora EÚ, t.j. v súlade s Ústavou Slovenskej republiky, verejným poriadkom, princípmi, na ktorých spočíva tento zákon, s medzinárodnoprávnymi záväzkami Slovenskej republiky, ktoré majú prednost' pred zákonom, judikatúrou Európskeho súdu pre l’udské práva a Súdneho dvora Európskej únie, a to s trvalým zretel'om na hodnoty, ktoré sú nimi chránené.

${ }^{20}$ ČENTÍK, T. - ŠTEVČEK, M.: Čl. 16 [Princíp použitel'nosti nezákonného dôkazu a zákazu reformatio in peius]. In: ŠTEVČEK, M. - FICOVÁ, S. - BARICOVÁ, J. - MESIARKINOVÁ, S. - BAJÁNKOVÁ, J. TOMAŠOVIČ, M. a kol.: Civilný sporový poriadok. Komentár. Praha : C.H. Beck, 2016, s. 66.

${ }^{21}$ Dôvodová správa k zákonu č. 161/2015 Z. z. Civilný sporový poriadok.
} 


\section{PRÁVNE ROZPRAVY ON-SCREEN III. - Sekcia súkromného práva}

online vedecká konferencia - 7. máj 2021

argumentácia súdov založená na ustanoveniach o ochrane osobnosti podl’a § 11 a nasl. Občianskeho zákonníka. ${ }^{22}$

Na záver zjednodušené povedané, ak sa súd ocitne v situácií resp. pozícií, že strana sporu predloží nezákonný dôkaz, nemôže ho automaticky stroho odmietnut', ale musí v zmysle článku 3 ods. 1 a článku 16 ods. 2 Civilného sporového poriadku pristúpit' k testu proporcionality, ktorý predstavuje postup súdu, v rámci ktorého súd hodnotí, ktoré právo garantované Ústavou Slovenskej republiky v danom prípade zaváži viac a má väčšiu dôležitost'.

\section{Záver}

Nevyhnutným základom každého rozhodnutia sú skutkové zistenia, ktoré súd získava prostredníctvom dokazovania, a teda proces dokazovania je dôležitou súčast'ou všetkých konaní a je obligatórnym krokom $\mathrm{k}$ docieleniu efektívneho, spravodlivého a účinného výsledku konania.

Nová právna úprava účinná od 01. júla 2016, ktorá nahradila viac ako pät' dekád platný a účinný Občiansky súdny poriadok, výrazným spôsobom priniesla zefektívnenie, zhospodárnenie a zrýchlenie spravodlivosti, ako aj ochrany práv a právom chránených záujmov účastníkov procesného konania a aj čiastočné objasnenie toho, ako sa ma súd postavit' k nezákonne získaným dôkazom resp. nezákonnému dôkazu.

V zásade platí, že dôkaz získaný nezákonným spôsobom je neprípustný. V dôvodovej správe k Civilnému sporovému poriadku je však uvedené, že „celkom výnimočne môže odôvodnenost' postupu mimo rámca princípu legality vyplývat' z tzv. testu proporcionality vzájomne kolidujúcich ústavných práv. V tomto zmysle napr. súd môže vykonat' dôkaz získaný v rozpore so zákonom, ak je právo protistrany ústavnokonformne posúdené ako v konkrétnom prípade silnejšie právo než porušené právo toho, na koho úkor sa právo vykonáva. Ak teda napriklad súd vezme do úvahy elektronickú komunikáciu či zaznamenanie obrazu a zvuku na to určenými elektronickými prostriedkami, ktoré boli získané bez súhlasu osoby, ktorej prejavy boli takto zachytené, musi to odôvodnit' tým, že právo na ochranu osobnosti tohto subjektu je v konkrétnom prípade proporčne slabšie oproti tomu ústavnému právu, ktorého

22 ŠTEVEČEK, M. a kol.: Prednášky a texty z (nového) civilného procesu. Skriptá. Bratislava : C. H. Beck, 2017, s. 93. 


\section{PRÁVNE ROZPRAVY ON-SCREEN III. - Sekcia súkromného práva}

online vedecká konferencia - 7. máj 2021

porušenie sa má takto získaným dôkazným prostriedkom preukázat’ (v zmysle judikovaných záverov môže ist' napr. o proporčne silnejšie právo na rasovú, rodovú, či inú nediskrimináciu). “

Z pohl'adu de lege ferenda $v$ súvislosti s úpravou prípustnosti nezákonne získaného dôkazu v civilnom súdnom konaní je potrebné zjednotit' súdnu prax, vytvorit' ustálenú judikatúru aj v právnom prostredí Slovenskej republiky, nakol'ko prípustnost' nezákonne získaného dôkazu sa posudzuje vzhl'adom na okolnosti prípadu vždy odlišne, avšak doposial' sa spravidla vychádza práve z judikatúry Českej republiky, odkial' pochádzajú klúčové argumenty.

\section{ZOZNAM BIBLIOGRAFICKÝCH ODKAZOV}

FICOVÁ, S. a kol.: Občianske právo procesné: základné konanie. Bratislava : Univerzita Komenského v Bratislave, Právnická fakulta, Vydavatel'ské oddelenie, 2008, 438 s. ISBN 978-80-7160-256-9.

GANDŽALOVÁ, D.: Osobitosti dokazovania v nových civilnoprávnych predpisoch so zameraním na správny súdny poriadok. In TUROŠÍK, M. - ŠEVČIKOVÁ, A.: Zborník z III. ročnika medzinárodnej vedeckej konferencie BANSKOBYSTRICKÉ ZÁMOCKÉ DNI PRÁVA na tému „Identifikácia únosnej miery autonómie právnych odvetví a súčasnej potreby ich synergie". Banská Bystrica : Belianum. Vydavatel'stvo Univerzity Mateja Bela, 2018, s. 58 70. ISBN 978-80-557-1405-9. [online]. Dostupné na internete: https://www.prf.umb.sk/app/cmsSiteAttachment.php?ID=4300.

ŠTEVČEK, M. - FICOVÁ, S. - BARICOVÁ, J. - MESIARKINOVÁ, S. - BAJÁNKOVÁ, J. - TOMAŠOVIČ, M. a kol.: Civilný sporový poriadok. Komentár. Praha : C.H. Beck, 2016. 1540 s. ISBN 978-80-7400-629-6.

ŠTEVČEK, M. a kol.: Prednášky a texty z (nového) civilného procesu. Skriptá. Bratislava : C. H. Beck, 2017. 164 s. ISBN 978-80-89603-51-0.

VLČEK, R.: Dôkazné prostriedky v občianskom súdnom konaní z právneho, sociologického a psychologického pohl'adu. Bratislava : Epos, 2006. 206 s. ISBN 80-8057-683-1.

ZÁHORA, J. a kol.: Dokazovanie v trestnom konaní. Praha : Leges, 2013. 318 s. ISBN 97880-87576-76-2. 


\section{PRÁVNE ROZPRAVY ON-SCREEN III. - Sekcia súkromného práva}

online vedecká konferencia - 7. máj 2021

Uznesenie Ústavného súdu Slovenskej republiky zo dňa 20.01.2015, sp. zn. III. ÚS 21/2015-14.

Uznesenie Najvyššieho súdu SR zo dňa 24.02.2010, sp. zn. 4Cdo/13/2009.

Uznesenie Najvyššieho súdu Slovenskej republiky zo dňa 16.06.2009, sp. zn. 4Cdo/188/2008.

Ústavný zákon č. 460/1992 Zb. Ústava Slovenskej republiky v platnom znení.

Zákon č. 160/2015 Z. z. Civilný sporový poriadok v platnom znení.

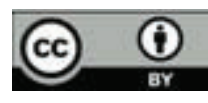

Obsah článku podlieha licencii Creative Commons Attribution 4.0 International Licence CC BY (Simona Smolková - Jakub Dzimko). 